\title{
Implications of Self- and Other-Representation in Representing Translation History: With Special Reference to the History of Translation in the Abbasid Era
}

\author{
Bilal Sayaheen
}

\author{
Department of Translation, \\ Yarmouk University, Jordan \\ Raidah Al-Ramadan \\ Department of Translation, \\ Yarmouk University, Jordan
}

Doi: 10.36941/jesr-2020-0035

\section{Abstract}

This study investigates two different ways of representing translation histories, namely, self-representation and other- representation. Moreover, this paper sheds some light on a part of the translation history during the Islamic golden age, specifically, the Abbasid Era. The current study analyzes two different books about the translation history during the Abbasid Era: O'Leary's book (How Greek Science Passed to the Arabs, 1949) and Al-Khalili's book (The House of Wisdom: How Arabic Science saved Ancient Knowledge and Gave Us the Renaissance, 2011). The purpose of the analysis is to gain a hint about how people write the history of translation and what factors, either cultural or ideological, interfered in shaping that history. Moreover, considering Al-Khalili's book as an example of self-representation and O'Leary's book as an example of otherrepresentation should help in revealing types of convergences and divergences between these two books in representing translation history. The results of the analysis show that there were instances of convergences and divergences between these two books in representing translation history.

Keywords: translation histories, self-representation, other-representation, Abbasid Era, and House of Wisdom

\section{Introduction}

Writing translation histories is one of the most important topics in the field of translation studies. Usually, translation historians write history by using different methods such as the descriptive method or the interpretative approach (See Wakabayashi, 2013, Crisafulli 2014, O'Sullivan, 2012, Rundle 2012, and 2014). The descriptive approach designates to the types of research that describe certain phenomena in the field of translation studies whether it is empirical or non-empirical. Crisafulli 2014 suggests that historians adopting the descriptive approach are not expected to draw conclusions and/or recommendations. On the other hand, the interpretative approach refers to the historians' and theorists' explanations of a given phenomenon. The supporters of the descriptive approach (such as Toury) claim that descriptive approaches are scientific and thus exclude bias. On the contrary, opponents of the descriptive method claim that it can involve bias. In this regard, Crisafulli 2014 explains "One has to acknowledge that no descriptive framework is immune to 
interpretive bias". (p.32). The usage of a specific method at the expense of another depends on the questions that the historian wants to find answers for or on the facts that he/she wants to reveal. This paper aims at exploring two different ways of representing translation histories, namely, selfrepresentation and other- representation. Both methods refer to representing people and events in a translation context in a certain period in a certain culture or community. Historians or researchers who belong to the represented culture are the ones who usually write self-representation. However, representation of the other can also be carried by historians or researchers from other cultures.

Moreover, to add value to the argument, this paper sheds some light on a part of the translation history during the Islamic golden age, specifically, the Abbasid Era. The Abbasid dynasty is considered as one of the greatest Islamic dynasties. Islamic golden age is a remarkable period in the Islamic history which lasted from the raise of the Abbasid Caliphate in 750 until the collapse of the Abbasid Caliphate in 1258. The Islamic Golden Age witnessed remarkable developments and advancements in many fields such as; medicine, algebra, physics, chemistry, mathematics and astronomy. (See, Renima et al, 2016 and Matthew, 2006). The Islamic Golden Age came to an end when Mongols invaded and thrashed Baghdad, the capital of the Abbasid Caliphate, under the leadership of Hulagu Khan. (See Kennedy, 2016 and Liu, 2011).

The Islamic Golden Age witnessed the establishment of The House of Wisdom (Arabic: Bayt alHikhma), which was a library, a translation institute and a research center in Baghdad, Iraq. It was the main institution in the translation movement and was considered a major intellectual hub during the Islamic golden age. O'Leary (How Greek Science Passed to the Arabs, 1949) and Al-Khalili (The House of Wisdom: How Arabic Science saved Ancient Knowledge and Gave Us the Renaissance, 2011) authored two different books about the translation history during the Abbasid Era. Analyzing these books may give us a hint about how people write the history of translation and the factors, cultural or ideological, that interfered in shaping the history in question. Moreover, considering Al-Khalili's book as an example of self-representation and O'Leary's book as an example of other-representation should help reveal types of convergences and divergences between the two books. Here, it is important to mention that Al-Khalili is an Iraqi author and historian who was born and educated in Baghdad, Iraq. And O'Leary is a British historian, Orientalist and lecturer who was born in 1872 in the United Kingdom.

\subsection{Self-representation}

First, some views of the notion of representation will be presented. Hall (1997), for example, defines representation as "using language to say something meaningful, or to represent, the world meaningfully, to other people" (p.15). Salazar (2008) states that "Cultural representation help form the images people have of others" (p.1). These two views suggest that representation involves presenting something to someone or to the world. Moreover, the latter view explains the importance of representation in establishing and determining the image of others as well as appearance as expressed by certain authors to certain cultures. Shohat and Stam (1994) argue that, in many languages, "to represent" means "to enact" or to play a role. The given definition suggests that the presenter plays a role in the process of representation, i.e., representors are involved in shaping ones and others history (p.182).

In what follows, the two concepts: "Self" and "Other" will be discussed in their relevance to the current study. "Self" refers to anyone from inside a specific culture or society, whereas "Other" refers to anyone from outside a culture or a society. Thus, self-representation simply means that people of a specific culture take the responsibility of representing their own culture or history. Otherrepresentation refers to the act of writing about a culture or a nation other than that of the author. The suggested definition can also be applied to translation history writing since translation historians can write about their own history or others' histories.

Many factors in both self and other- representation may influence the process of representation. Among these factors are ideology, power, and interpretation of historical events. Some cultures 
choose self-representation to write about their translation histories to introduce a purified image about themselves and to promote a better understanding and a deeper respect of the represented culture among the target culture reader. Yet, interpretation is involved in representation, which led some scholars to question whether representations are Self or Other representations (Shohat, 1995). Other scholars emphasize that representation does not happen in a vacuum, hinting that it is not an objective process (Tymoczko, 2006). Considering power as a factor in representation, Spivak's article "Can the Subaltern Speak" (1998) provides a thorough understanding. Spivak argues that representation is a kind of speech act, where we have a speaker and a listener. The Subalterns try to represent themselves, but their act of representation is not heard because the listener does not recognize it. In other words, due to the unequal scale of power among cultures and societies, some cultures are more likely to be heard than others. Consequently, if some cultures are more likely to be heard than others, they are more likely to be followed in establishing and forming the images of the Other. The constructed images by the dominant about the dominated or the 'Subaltern' can include personal interpretations and judgments. Moreover, if, as argued by Tymoczko, representation is subjective, then the images represented by the Self or the Other can be reduced or manipulated for ideological reasons.

\section{Other representation}

As discussed in the previous section, other- representation refers to any work done by scholars or historians about cultures or societies other than their own. We believe that some light should be shed on these types of writing in order to see if they differ from self-writings. Firstly, we would argue that all historians, whether "self" or "other", deal with events that happened in the past. Thus, they both depend on sources to write about a certain history. In other words, "other" may have access to more sources than "self" or vice versa. Secondly, both "self" or "other" adopt certain methodologies to represent a certain history, and methodologies are not exclusive to the privilege of a certain scholar or historian; they are there, and anyone can adopt them. Up to this point, none of them, "self" or "other", is considered more qualified or even more capable than the other to document or study a certain history. As for motivation, anyone may get interested in a particular culture, literature and/or a nation, and that passion may drive the person to write about the history of that culture or literature. Passion for writing about history of translation, of course, is not enough as it should be accompanied by knowledge in both translation studies and history.

There are various factors that may play a role in representations carried by the "Other". These factors include stereotypes, power, ideologies and interpretations. The last two factors can be said to affect both Self and Other representation. However, the first two are most likely to affect Other representation. Consider the following:

Non-Western cultures and societies have been represented, translated, according to fixed ideologies and discursive strategies. Africans, Arabs, Muslims and Israelis, as well as Central and Eastern Europeans, have been, and still are, seen as 'trouble-makers and sources of nuisance' for the Western world, which finds itself time and again having to intervene to solve their problems and bickering" (Faiq, 2005, p.2)

Such ideologies may affect the representation of these cultures in media and in writing translation history as well. Here, it is important to define ideology. Mason (2010) defines ideology "as the set of beliefs and values which inform an individual's or institution's view of the world and assist their interpretation of events, facts and other aspects of experience" (86).The impact of stereotypes and unchanging ideologies will be discussed in the following section. Consider for example how some stereotypes about Arabs shaped Disney's Aladdin and the Arabian Nights:

Even though most Westerners may not know who Abbasids were, references to the caliph of Baghdad or Harun al-Rashid conjure up images of Disney's Aladdin and The Arabian Nights-a never-never land of flying carpets, genies released from magic lamps, and scattering gold and jewels. (Goldschmidt,2003, p.73) 
This shows how Disney, i.e., "other" perceives the Abbasids Era according to certain previously established stereotypes and then conveys this image to its audience. This picture may influence anyone who relies on these films to construct his/her knowledge about the Abbasid Era.

Moreover, the issue of power can affect the writing of translation history. As we illustrated above, some cultures are more likely to be heard than others. This can happen in writing the history of translation, especially when a writer from a dominant culture writes about non-dominant culture. Thus, he/she will more likely to be read than others.

\section{Discussion and Analysis}

This section attempts to provide both an analysis and a comparison of two books that tackled translation history during the Abbasid Era. The first book is entitled "How Greek Science Passed to The Arabs." It was written by D. O'Leary, who is a British historian and lecturer in the Aramaic and Syriac languages at the University of Bristol. The second book is entitled "The House of Wisdom," which was written by Al-Khalili, an Iraqi author and historian. For the purposes of this study, O'Leary's book will be considered an example of Other-representation, while Al-Khalili's will be considered as an example of Self-representation. Both books tackle various topics, but this paper is concerned only about the specific period of the Abbasid Era.

First let us provide a brief about the translation movement at that time. Al-Khalili argues that translation movement is "a process that lasted for two centuries- during which much of the wisdom of the earlier civilizations of the Greeks, Persians and Indians was translated into Arabic" (2005, p.35). O'Leary also mentions the translation movement, referring to it as "a movement which aimed at translating Greek scientific material into Arabic (1949, p.155). The translation movement started in the mid-eighth century and was supported by both the Caliphs and wealthy Muslim patrons. The main aim of the movement was to transfer Greek, Indian, and Persian knowledge, wisdom and sciences such as mathematics, medicine, astrology, physics, engineering, chemistry, etc. to the Islamic Empire.

After a thorough examination and analysis of the relevant parts in both Al-Khalili's book and O'Leary's book, it can be argued that several convergences and divergences between these two books have been detected in terms of representing the translation history in the Abbasid Era. The convergences have been seen to be a result of representing self-evident events and historical facts. In contrast, divergences can be attributed to different interpretations of historical events, using different sources to prove evidence, and sometimes, to different ideologies. These ideologies, in turn, come as a result of self and other representations.

In relevance to the convergences, it seems that both authors agreed on certain major issues and events. For example: (1) they both admitted the existence of "The House of Wisdom" and the translation movement during that era and they both stated that "Al-Ma'mun" was the founder of "The House of Wisdom"; (2) they both agreed that "Hunayn Ibn Ishaq" was the most famous translator during the Abbasid Era; (3) they both agreed that Persians influenced the Abbasid Caliphs; (4) they both agreed that the earliest translations from Greek were concerned with astronomy and mathematics; (5) they both agreed that Caliphs and wealthy people patronized and encouraged the translation movement. The above mentioned five points comprise the major events and issues during the Abbasid Era. Here it is of importance to add that while both books and historians admitted the existence of "The House of Wisdom", they did not agree on the role that the House of wisdom had played in enriching science and civilizations in general. For example, Al-Khalili asserts in different places of his book (See pages, 35, 36, 71and 73) that Muslim and non-Muslim scholars during that era did not only translate sciences from other cultures. Al-Khalili explains that after translating the Greek, Indian and Persian knowledge, science and wisdom, scholars of Baghdad began to question, extend and improve upon the knowledge they had acquired" (p. 79). Al-Khalili went further to criticize what he calls "the naïve Eurocentric" (p. 79) views about the translation movement during the Abbasid era. He explains that the Westerners depict the movement as merely transferring knowledge from other civilizations to the Islamic Empire without mentioning or clarifying that the 
translation movement involved improving and extending that imported and translated knowledge. Meanwhile, O'Leary did not mention that translators during the Abbasid Era attempted to reflect on and develop the books they translated.

On the other hand, after thorough analysis of the relevant parts of the two books we can point out some divergences and attempt to find the reasons behind them. The two books provided different reasons that led to the advent of the translation movement. Al-Khalili believes that the main reasons are: (1) the Abbasid obsession with Persian culture;(2) their obsession with astrology; and (3) the serendipity of emerging technologies. On the other hand, O'Leary did not discuss this issue in detail, but he mentions that Harun's minister, Ja'fer Ibn Barmak, played a crucial role in influencing him to support translations from Greek into Arabic. Moreover, O'Leary clearly states that supporting and promoting translation was seen as a mode of 'fashion'. O'Leary went further to claim that the main motive for translating was not "a pure love of science" (161). This could be attributed either to the different sources that both authors used to study that era or to the differences in interpreting events such as the relationship between the Abbasids and Persians. More importantly, self and otherrepresentation can be the major drive for analyzing and interpreting the reasons for the rise of translation movement during the Abbasid Era. In other words, Al-Khalili, as an example of selfrepresentation, suggests that, in addition to the influence of Persian culture, Muslims need to know how to, for example, "determine the times of prayer and the direction of Mecca". (67) Islamic culture turned into a "culture that encouraged free and creative thinking across a wide range of disciplines". (67). On the other hand, O'Leary, as an example of other- representation, states that Persian influence was the major reason behind the interest in science and translation during Abbasid Era. In addition to that, O'Leary claims that encouraging translation became 'a fashion at court' (161) and thus indicating that the passion towards translating was a way to flatter, impress, or even to get closer to the Caliph's court. Finally, O'Leary seems to be willing to give credit to non-Arabs in developing, encouraging and sponsoring translation during the Abbasid Era. O'Leary plainly suggests, "The Arabs generally took little interest in it" (161).

Another difference is related to the relationship between the Abbasids and Persians; both authors agreed that Persians influenced Abbasid culture and politics. However, O'Leary went further and said that Persian families "to a great extent controlled the Abbasid government." (p.155). Again, this difference has to do with the evidence and sources that both authors used.

Apart from the convergences and divergences that were observed in both books. We believe certain expressions, phrases, and stories should be highlighted. Al-Khalili states that "By the middle of the ninth century the House of Wisdom would have become the largest repository of books in the world." (p.71). This example could be seen as a way to promote a deeper respect for that era, i.e., The Abbasid, among the target culture readers. Moreover, Al-Khalili attempts to celebrate the translation movement during the Abbasid Era by highlighting the lack of research and writing on this specific crucial movement.

On the other hand, two quotations from O'Leary's book are mentioned and analyzed here. In describing Caliph Al-Ma'mun, O'Leary says "At Baghdad he was welcomed with great rejoicings. He was a man of handsome presence, a thing which counts for much in the oriental princes." The author also describes him as "Pro-Persian and anti-Arab, son of a Persian mother and married to a Persian wife" (p.162). The first example expresses a typical stereotype about Arabs; it suggests that Arab care too much about the physical appearance of a prince. Here, it is very important to define and explain what is mean by orientalism. Said (1977) defines it as:

Orientalism is a style of thought based upon an ontological and epistemological distinction made between "the Orient" and (most of the time) "the Occident." Thus a very large mass of writers, among whom are poets, novelists, philosophers, political theorists, economists, and im-perial administrators, have accepted the basic distinction between East and West as the starting point for elaborate theories, epics, novels, social descriptions, and political accounts concerning the Orient, its people, customs, "mind," destiny, and so on. (2) 
Defining and describing Caliph Al-Ma'mun as an "oriental prince" may impact the readers of the book by the set of reduced and limited images of the Orient and its people. Moreover, the inclusion of the adjective oriental can be seen as a device to further attract Western readerships as it confirms to their expectations about the East.

The second example lists four qualities of Al-Ma'mun. Three of them-that he was Pro-Persian, the son of a Persian mother and married to a Persian wife-are acknowledged facts. However, the fourth one raises some questions and makes readers wonder why an Arab Caliph hated his own nation. Moreover, O'Leary did not provide any evidence to show that Al-Ma'mun was anti-Arab; he only shows that he was pro-Persian, which doesn't necessarily mean that he was anti-Arab. Describing, labeling and accusing an Arab Muslim Caliph to be anti-Arab demanded extensive research in the history of that era, i.e., Abbasid Era, in general, and Al-Ma'mun's era in specific. Consequently, the History of al-Tabari was consulted to verify the accusation raised by O'Leary against Al-Ma'mun. History of al-Tabari is considered as 'fundamental' and 'invaluable' (See SUNY Press and Young, 2006) source of historical events written by the Muslim historian and scholar Abu Ja far Muhammad ibn Jarir al-Ṭabari. In addition, the book was translated into English. A critical analysis of Al-Ma'mun's era shows that He favored Persians in many instances but was never described as anti-Arab. In other words, accusing an Arab Muslim Caliph as anti-Arabs raises many questions about the purpose and the validity of this label. On the other hand, Al-Khalili admits the Persian influence during the Abbasid Era but never describes Al-Ma'mun as anti-Arab. Time and again, both scholars, i.e., Al-Khalili and O'Leary present their personal interpretations of a set of historical events that confirm the existence and influence of Persians on the Caliph's court and the love of Al-Ma'mun to them. O'Leary went far beyond describing Al-Ma'mun as a pro-Persian to say that he was anti-Arab, while Al-Khalili did not.

\section{Conclusion and Results}

The current paper analyzed two books that tackled the history of translation in the Abbasid era. The first book, "The House of Wisdom", is considered as Self-representation and the second one, "How Greek Science Passed to The Arabs", is considered as Other- representation. We can conclude that the many issues and events during that era were represented by both the British and Arab scholars in a generally similar way. This similarity can be attributed to the nature of these events and issues, since they are agreed upon in many historical books, which may in turn, have been used by the authors of the two books. However, the analysis showed that there are some convergences between these two kinds of representations. The convergences may come out as a result of different interpretations of the historical events, using different sources to build evidence, and sometimes, to different ideologies. The latter reason seems to be influential for the existence of convergences between the two authors. The two authors disagree about the role of scholars in The House of Wisdom. On the one hand, Al-Khalili explains that scholars did not only translate sciences from the Greek, Indian and Persian cultures but also enhanced, examined, and expanded what they translated. On the other hand, O'Leary did not mention that translators during the Abbasid Era attempted to reflect and develop the books they translated. Another crucial difference in representing the translation history during the Islamic golden age, specifically, the Abbasid Era, lies in describing the role of one of the greatest sponsors to the translation movement i.e., the Caliph Al-Ma'mun. O'Leary and Al-Khalili admit the role of Al-Ma'mun in sponsoring the translation movement. However, they differ in interpreting the reasons and motives that drove Al-Ma'mun's passion towards translation.

The issue of convergences and divergences is thought to exist as long as some historical events are subject to the writers' own interpretations, which can vary among writers. However, scholars can approximate these convergences and divergences by starting writing histories of translation in teams, which include translation studies historians and historians who represent both sides, Self and Other. These sides can collaborate to write "better" histories that are built on both sides' points of view. 


\section{References}

Al-Khalili, J. (2011). The house of wisdom: how arabic science saved ancient knowledge and gave us the renaissance. New York: The Penguin Press.

Andre, J., and Hsiao-yen, P. (2012). China and its others: knowledge transfer through translation, 1829-2010. Amsterdam and New York: Rodopi.

Crisafulli, E. (2014). The quest for an eclectic methodology of translation description. Crosscultural Transgressions. Research Models in Translation Studies, 26-43.

Faiq, S. (ed.) (2005). Introduction: translation, representation, and identity in Intercultural Communication. Intercultural Communication Studies. Vol. XIV:4. 1-3.

Goldschmidt, A. (2002). A concise history of the middle east. Boulder and Oxford: Westview.

Hall, S, ed. (1997). Representation: cultural representation and signifying Practices. London: Open University Press. http://en.wikipedia.org/wiki/House_of_Wisdom. Retrieved February 3 (2018).

Kennedy, H. (2016). The early Abbasid Caliphate: a political history. Routledge. Routledge, 2016.

Liu, X. (2011). A silk road legacy: The spread of Buddhism and Islam. Journal of World History, 55-81.

Mason, I. (2010). "Discourse, Ideology and Translation". In Mona Bake (ed.) Critical Readings in Translation Studies. Abingdon: Routledge, pp. 85-95.

Matthew E. Falagas, Effie A. Zarkadoulia, and George Samonis. (2006). Arab science in the golden age (750-1258 C.E.) and today.The FASEB Journal 20:10, 1581-1586.

O'Sullivan, C. (2012). Introduction: Rethinking methods in translation history. Translation Studies, 5(2), 131-138.

O'Leary, D. (1949). How Greek science passed to the Arabs. London: Routledge \&Kegan Paul Ltd.

Renima A., Tiliouine H., Estes R.J. (2016). The Islamic Golden Age: A Story of the Triumph of the Islamic Civilization. In: Tiliouine H., Estes R. (eds) The State of Social Progress of Islamic Societies. International Handbooks of Quality-of-Life. Springer, Cham.

Rundle, C. (2012). Translation as an Approach to History. Translation Studies, 5(2), 232-240.

Rundle, C. (2014). Theories and methodologies of translation history: the value of an interdisciplinary approach.

Said, E. Orientalism. London: Penguin, 1977. Print.

Salazar, NB. (2008). Representation in postcolonial analysis. Retrieved from http://www.academia.edu/1199231/Representation_in_postcolonial_analysis

Shohat, E,.and Stam, R. (1994). Unthinking Eurocentrism: Multiculturalism and the media. London and New York: Routledge.

Shohat, E. (1995). "The Struggle over representation: casting, coalitions, and the politics of identification." In Roman de la Campa, E. Ann Kaplan and Michael Sprinkler, (eds.), Late Imperial Culture. New York: Verso, Print.

Spivak, G. (1998). Can the subaltern speak?In Nelson, C. and Grossberg, L. (eds.) Marxism and Interpretation of Culture. Urban, IL: University of Illinois Press. 271-313.

Țabarī, \& Rosenthal, F. (1988). The History of al-Tabari. State University of New York Press.

Temple, B. (2005). Nice and tidy: "translation and representation". Social Research Online. 10 (2). Retrieved from: http://www.socresonline.org.uk/10/2/temple.html

Toury, G. (2012). Descriptive translation studies and beyond: Revised edition (Vol. 10o). John Benjamins Publishing.

Tymoczko, M. (2006) Reconceptualizing translation theory: integrating non-western thought about translation. In Theo Hermans (ed.) Translating others, Vol. 1. Manchester: St. Jerome.

Venuti, L. (2005). Translation, history, narrative. Meta5o (3): 80o-16. http://www.erudit.org/revue/Meta/2005/v5o/n3/o11597ar.htmll

Wakabayashi, J. (2013). History of translation. The Encyclopedia of applied linguistics, 1-9.

Young, M. J., Latham, J. D., \&Serjeant, R. B. (Eds.). (2006). Religion, learning and science in the'Abbasid Period. Cambridge University Press. 